\title{
Web-Based E-Marketing Application for Balinese Art Studio
}

\author{
I Gede Wahyu Hardinugrahaa ${ }^{a 1}$, Oka Sudana ${ }^{\text {a2 }}$, Dwi Putra Githa ${ }^{\text {a3 }}$ \\ anformation Technology Study Program, Faculty of Engineering, Udayana University \\ Bukit Jimbaran, Bali, Indonesia, phone. (0361) 701806 \\ e-mail: ${ }^{1}$ wahyuhardi956@yahoo.com, ${ }^{2}$ agungokas@unud.ac.id, ${ }^{3}$ dwiputragitha@unud.ac.id
}

\begin{abstract}
Balinese art and culture are unique because they may not be found in other regions. This uniqueness provides a characteristic and an attraction for foreign and domestic tourists visiting the island of Bali. The art studio is a place to provide traditional performing arts. The constraints experienced by art studios generally prevail in the manual marketing of art services, while consumers experience problems ordering these performing arts services. The method used in this study includes five main stages, namely, requirements analysis, system design, implementation, testing, and system maintenance. This research produces an E-Marketing Application for Balinese Art Studio with a website as the mediator. The Black Box test results show that all the system functionality components have been running successfully. The questionnaire analysis based on the answer scale percentage results shows that this application has been running well, responds according to the data needed, and is very suitable to be applied to people, especially those who need assistance in ordering traditional performing arts services. The implementation of this application will indirectly be a means of promoting traditional performing arts.
\end{abstract}

Keywords: e-marketing, art studio, website, black box, questionnaire

\section{Introduction}

Talking about Balinese art and culture will never be separated from the religious rituals of the Hindu-Balinese community. This relationship is a unity that has long been complementary and inseparable. Indirectly, the relationship between art and culture and religious rituals has become unique because it is not necessarily found in other areas. This uniqueness has become a characteristic and an attraction for foreign and domestic tourists when visiting Bali. Art and cultural heritage are essential to be preserved, but it is not easy, especially in the midst of increasingly rapid times. One way to preserve art and culture is to provide a place or place, such as an art workshop.

Generally, the art studio will accommodate art actors to develop artistic potential following their respective artistic expertise. Traditional performing arts are among the many art studio branches because traditional performing art's role is very dominant in society. This need is genuine when the Hindu-Bali community holds a religious ritual. Besides functioning as a complement to religious rituals, traditional performing arts can also be performed as entertainment for people who need these traditional performing arts services.

Gamelan and dance are examples of art categories included in traditional performing arts. Balinese Gamelan performance services, which are generally often needed by the community, for example, are Gamelan Pelegongan, Gamelan Gambang, Gender Wayang, Gong Kebyar, and Balinese Angklung. For example, Balinese dance services are Rejang Dance, Legong Dance, Mask Dance, and Pendet Dance. Based on the interview data obtained for this study, it can be said that most of the art studio experienced problems in marketing gamelan and dance services. These constraints are caused by the marketing of art services carried out by art studio manually through word of mouth (not using an online system).

Electronic Marketing (E-Marketing) is a marketing strategy that utilizes internet technology. The concept of e-marketing is almost the same as traditional marketing, but what distinguishes it is the media [1]. Accordingly, an e-marketing application that helps in marketing and ordering traditional performing arts services (gamelan and dance) and is also used as a material for writing a proposal with the title: "Web-based E-Marketing Application for Balinese 
Art Studio". This study has necessary references from several previous studies, which will be described as follows.

The research that was conducted in the village of Gulang took the target of micro, small and medium enterprises which are engaged in the bag making industry. One of the obstacles faced is the lack of a business development strategy because it still uses the traditional marketing system (traditional markets). The design of this study used UML (Unified Modeling Language) tools. The results of this study are analysis and design of e-marketing for bag craftsmen in Gulang which is expected to be able to reach a wider market so that it can improve the economy of the community, especially bag craftsmen [2].

The next research aims to promote Balinese traditional arts and facilitate tickets to witness traditional performing arts performances to the public through a system. There are three main features in the system, namely show booking, ticket reservation, and online payment for booked shows. This research is a web service geographic information system developed with the programming language PHP, MySQL database, and the cloud [3].

Research that takes the pupuh case study (Tembang Bali) will introduce song lyrics made using the Finite State Automata method to separate syllables. This system can recognize stanza lyrics based on padalingsa rules such as the number of lines in one stanza, the number of syllables in each last vowel line and the last vowel in each line [4]. Subsequent research has produced an Android-based flower ordering application that aims to simplify product marketing and reach many consumers via smartphones. The software used in making this application is Eclipse using the Hybrid Apps method, a combination of Java and PHP using the WebView function [5].

Subsequent research uses the Forest Tree model to create a Balinese Gamelan information system. This research was held that it looked at community problems, namely disinformation regarding Balinese Gamelan. Besides, Balinese Gamelan also has close links with other cultures such as Balinese Dance and Balinese Tembang. This research aims to provide education to the public to get to know Balinese Gamelan and its relationships [6]. Research conducted at the Getar Pakuan Art Studio in Bogor raised a problem, namely manual ordering of performing arts. Customers must come directly to the studio's location when they want to order a performance, other than that the information obtained by the customers is less efficient. The method used in making this system is the Waterfall method which includes the analysis, design, coding, testing, support and maintenance stages. The result of this research is a website-based staging order information system that can be used in providing services to customers in providing performance order so that the information obtained by customers is in the form of an information system and can order art performances through an online system [7].

Research that has a background in introducing Gamelan Jegog from the Jembrana area, Bali is carried out through an application media using UML (Unified Modeling Language) tools. The results of the percentage of application trials are divided into three assessment scales, namely the "adequate" answer scale of $2.9 \%$, the "good" answer scale of $45.9 \%$, and "very good" of $51.2 \%$ [8]. The next research took a case study of traditional ceremonies in Bali, namely Bebayuhan Oton. The modelling system used in this study is a tree diagram. This information system was created due to several obstacles, namely the difficulty of arranging a meeting time with Sulinggih (a holy man who leads a ceremony) and a lack of knowledge about the Bayuh Oton ceremony. This research aims to implement the Tree Diagram model in building a website-based information system [9]. The research aimed at planning a search engine in the e-commerce web was conducted by applying the Latent Semantic method for information processing, the Text Mining method for word processing, and the Levenshtein Distance method for automatic word correction. The results of this study obtained a search engine accuracy rate of $96.7 \%$ [10].

Based on these studies, an idea emerged to conduct this research on the grounds that are looking at complaints from art studio about the limitations of manual art service promotion media, complaints from the public or consumers who find it difficult to order performing arts services, and the lack of information about traditional performing arts services, especially gamelan and dance. This study aims to create a Web-based E-Marketing application for Balinese Art Studio so that the marketing reach of art services becomes wider (not limited by space and time). The e-marketing application is built in stages with the waterfall method, equipped with main features such as registration, search for art services, chat messages, and ordering performing arts services. The programming languages used are PHP and MySQL as 
database management. This application is expected to be a solution to the complaints previously submitted.

\section{Research Method}

The methodology implemented in this research is the waterfall method. The waterfall method is a classic model that is systematic and sequential in building software. This model called the waterfall because each step that passed has to wait to complete the previous stage and runs sequentially [11]. The stages of this method seen as continuing to flow down like a waterfall. The following is an overview of this method's stages, which can be seen in Figure 1.

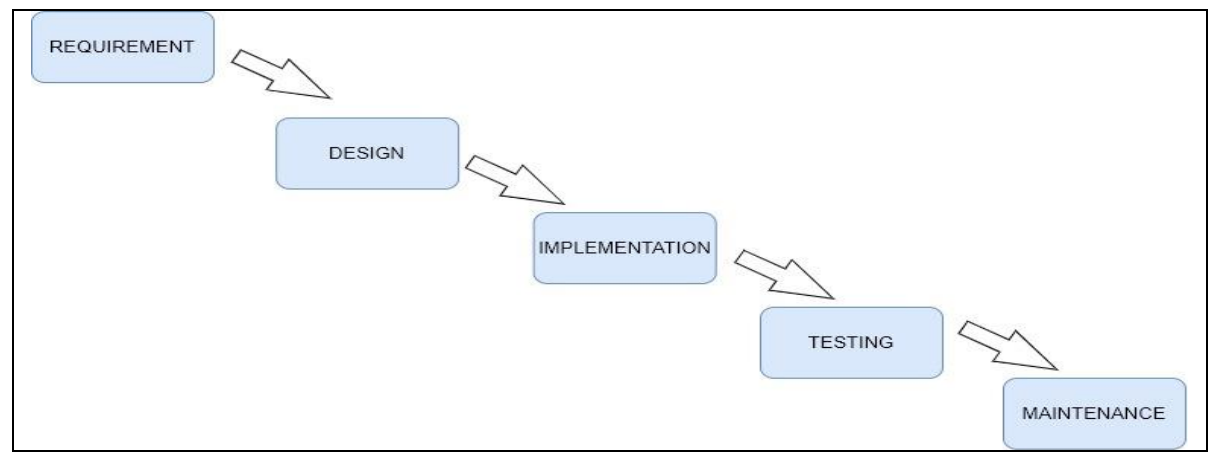

Figure 1. Waterfall Method Stages

Figure 1 is the waterfall method, which consists of 5 main stages, including needs analysis, system design, implementation, testing, and maintenance, each of which will explain as follows.

a. Requirements Analysis

This stage aims to identify the needs of the system to be created. One of them is conducting interviews with the art studio to obtain data as the main capital to the next stage.

b. System Design

This stage focuses on an overview of the system, system modeling, and user interface that interprets the functionality of each feature of the Web-based Art Studio E-Marketing Application that will be built later.

c. Implementation

Implementation is a stage that includes writing a program syncode that aims to translate the previously designed design, including system functionality. The implementation is carried out using the PHP programming language (Hypertext Preprocessor) and MySQL as database management.

\section{d. Testing}

This stage aims to test the system that has been completed before it is declared fit for use. System testing in this study uses the Black Box Testing method to test system functionality. Then the Likert scale questionnaire method aims to measure the attitudes and opinions of respondents.

\section{e. Maintenance}

This stage is the last in the waterfall method, aiming to correct errors found during system testing. At this stage, system updates are also carried out, especially in terms of features, aiming to make the system adapt to environmental needs.

\section{Literature Review}

The literature review contains the entire literature that is used as a reference in this study. Library sources were obtained through the internet, books, and journals, which aim to support the design and implementation of the Web-based E-Marketing application for Balinese Art Studio. 


\subsection{E-Marketing}

Electronic Marketing (E-Marketing) is a breakthrough in marketing, where a marketer uses information and internet technology to market products [12]. This strategy can be a more effective means of marketing a product or service.

\subsection{Art Studio}

The art studio is a place to study an art that aims to preserve it in society [13]. Art studios are included in the type of non-formal education because they are usually established individually or independently. The learning places and facilities in the studio depending on the conditions of each studio. Art studios usually have a private status, and for equalizing educational outcomes, they must go through an equivalent assessment process by an institution appointed by the government or local government to be equivalent to the results of formal education [14].

\subsection{Balinese Traditional Performing Arts}

Traditional performing arts are generally local. This art is created by local community groups and is also favored by these community groups [15]. Balinese traditional performing arts is a performing art that was born, developed, and has become a distinctive feature of Bali's traditional arts. Examples of traditional Balinese performing arts most commonly needed by the community are the gamelan and dance categories.

\subsection{System Overview} seen in Figure 2.

An overview of the Web-based E-Marketing Application for Balinese Art Studio can be

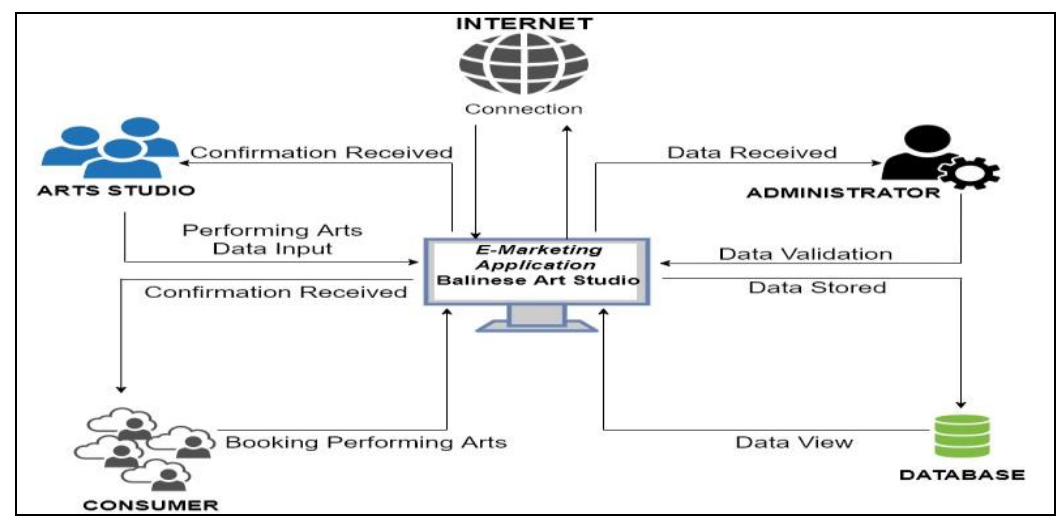

Figure 2. System Overview

Figure 2 is an overview that explains the role of each entity in the system. Administrator has a role in receiving every incoming data and is authorized to provide validation. The art studio plays a role in managing the performing arts data entered into the system and is responsible for every performance. Consumers have a significant role in making bookings (ordering) the performing arts services they want and receiving order confirmations through the system. All data in the system is loaded in the database and displayed on the system. An internet connection supports the entire process that occurs.

\subsection{Marketing Business Process}

The Marketing Business Process will discuss the stages that must be taken by the art studio if they want to do the marketing of gamelan or dance performing arts services through the system. 


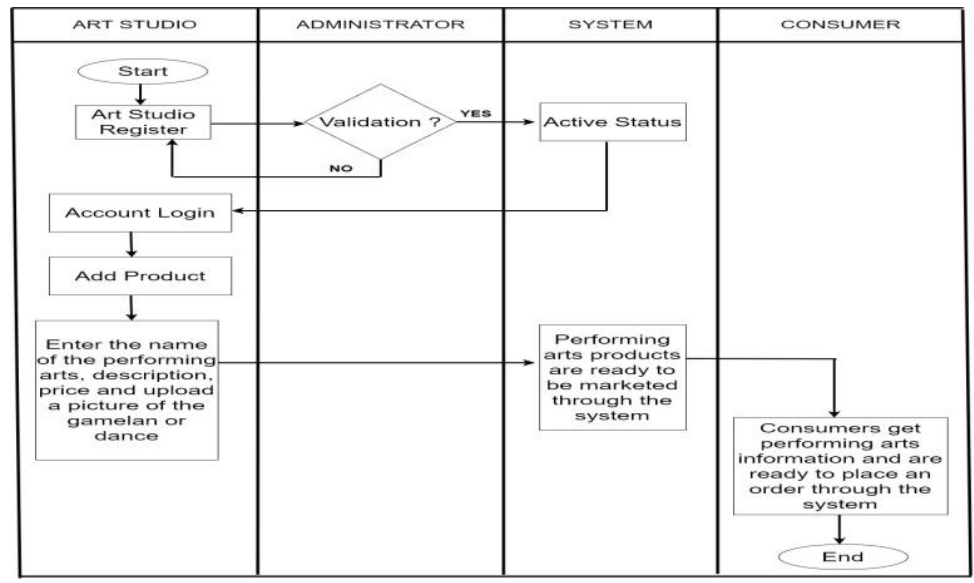

Figure 3. Marketing Business Process

The marketing process's business stage starts with the art studio registering and obtaining validation from the admin so that the account status becomes active. Each studio account will contain an add-product menu that allows you to enter performance art data including name, price description and image. Performing art data that has been entered will be automatically displayed on the main display of the art gallery e-marketing application, which then can be seen and ordered by all consumers who visit the system website. The comparison of manual marketing with the marketing of performing arts services online certainly affects increasing the target market. The reason is, if it is online, consumers can visit the website anytime and anywhere as long as they get internet access.

\subsection{Transaction Business Process}

A business process is a series of interrelated activities to achieve specific business goals that are completed sequentially by humans or systems [16].

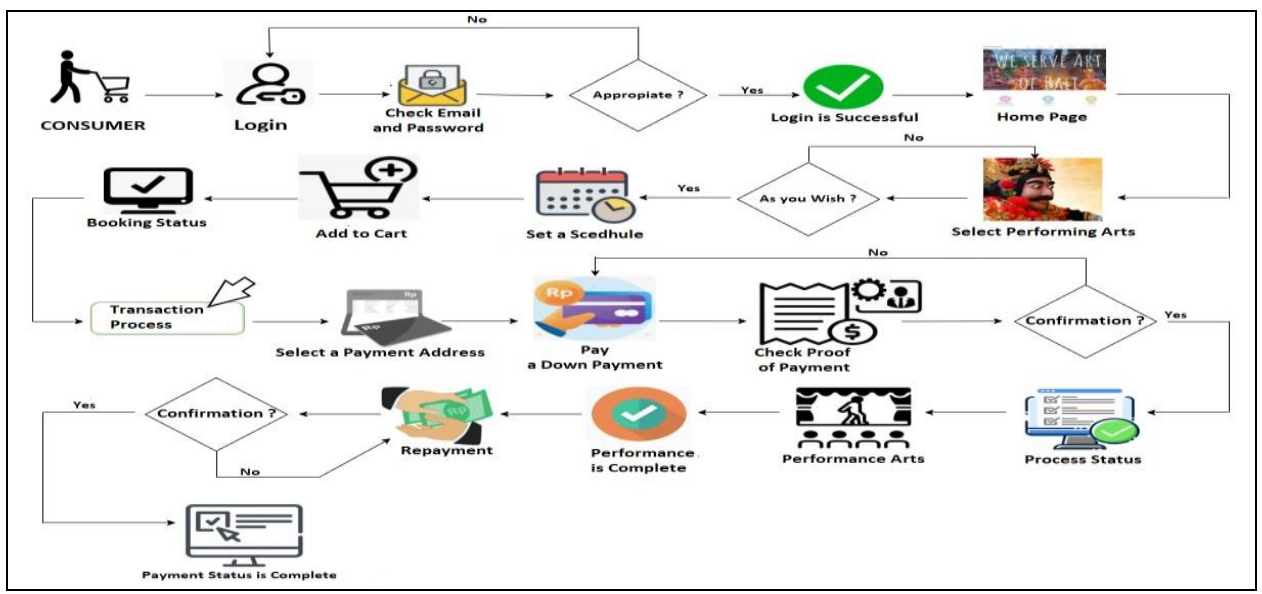

Figure 4. Transaction Business Process

Figure 4 is a business process flow, the stages starting with the consumer logging into the system by entering the correct email and password so that the login can be successful. Consumers who have successfully logged in will automatically go to the main page display. Then consumers are welcome to choose the desired performing arts service and determine the desired performance schedule. The next stage is to check out and transfer the down payment according to the amount printed on the system. Consumers who have transferred the advance payment will receive confirmation from the admin in the form of a change in payment status. If the performance has been completed, the consumer must complete one more stage, namely 
payment in full. After this, the customer will get a confirmation of the change in payment status to "completed."

\subsection{Context Diagram}

A context diagram is a general description of a system that shows the system's boundaries, the communication between an external entity and a system, and information generally flows between the entity and the system. A context diagram is a tool used in analyzing the system to be developed [17].

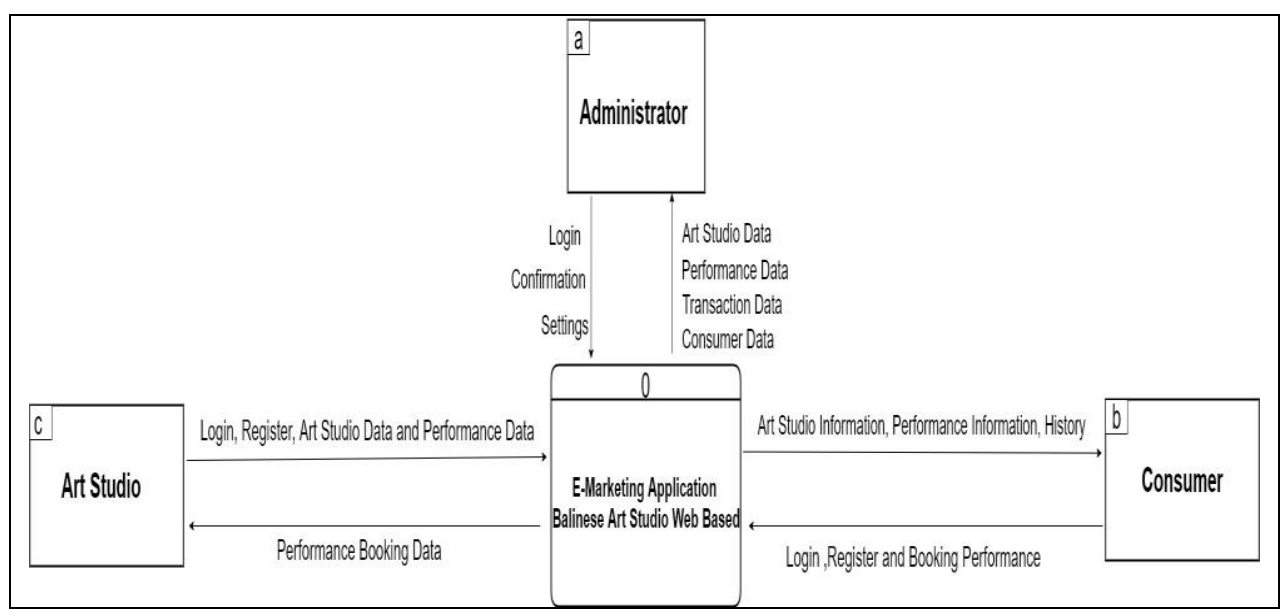

Figure 5. Context Diagram

Figure 5 is a context diagram of the Web-based E-Marketing Application for Balinese Art Studio, which shows data flow from each entity in the system. The administrator entity receives data, including studio data, performance data, consumer data, and transaction data. Administrator can also log in, manage, and validate data on the system. Art studio entities can register in the system or log in if they already have a studio account. The data entered by the art studio entity is the performance data and personal data of the associated studio. The data that flows from the system is shown as booking data from consumers who want to order a gamelan or dance performance. Consumer entities can log in, register, and book the show they want to perform on the system. Data that flow from the system to consumers include information about art studios, performing arts services, and shopping confirmation.

\subsection{Data Flow Diagram Level 0}

Data Flow Diagrams (DFD) is a data logic model or process created to describe where the data comes from and where the data comes out of the system, where the data is stored, what processes produce the data, the interaction between the stored data and the processes imposed on it [18]. 


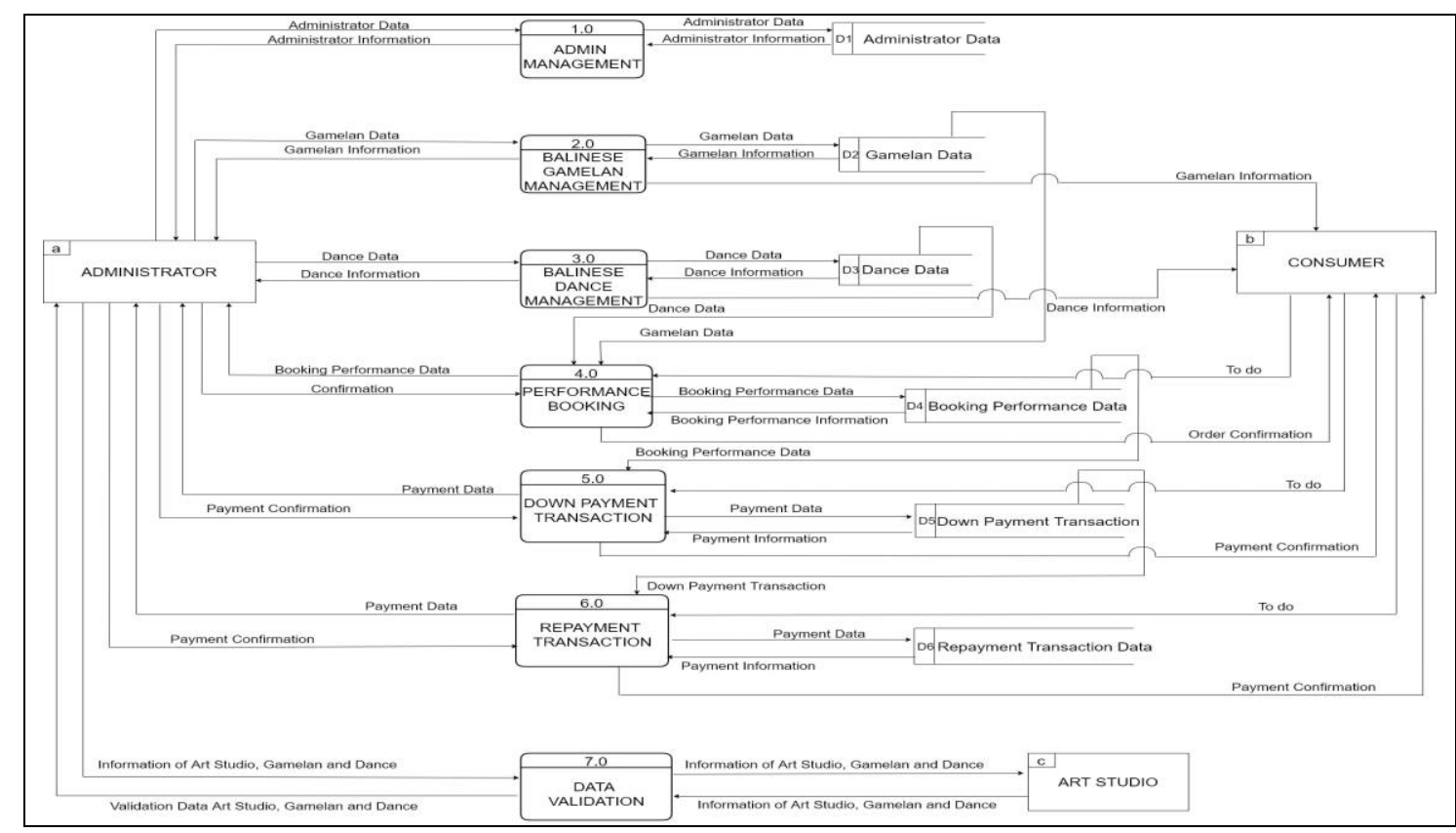

Figure 6. DFD Level 0

The Web-based E-Marketing Application for Balinese Art Studio uses DFD level 0 to present each system's main processes. These processes include admin management, gamelan management, dance management, show bookings, down payment transactions, payment transactions, and data validation. The main process is related to the entities in the system.

\section{Result and Discussion}

The results and discussion will discuss the implementation, testing, and analysis of the questionnaire from the Web-based E-Marketing Application for Balinese Art Studio.

\subsection{Implementation}

The implementation of Web-based E-Marketing Application for Balinese Art Studio is divided into two processes, namely marketing and transactions. Each of these processes has a relationship with 3 entities, namely consumers, the art studio and the administrator.

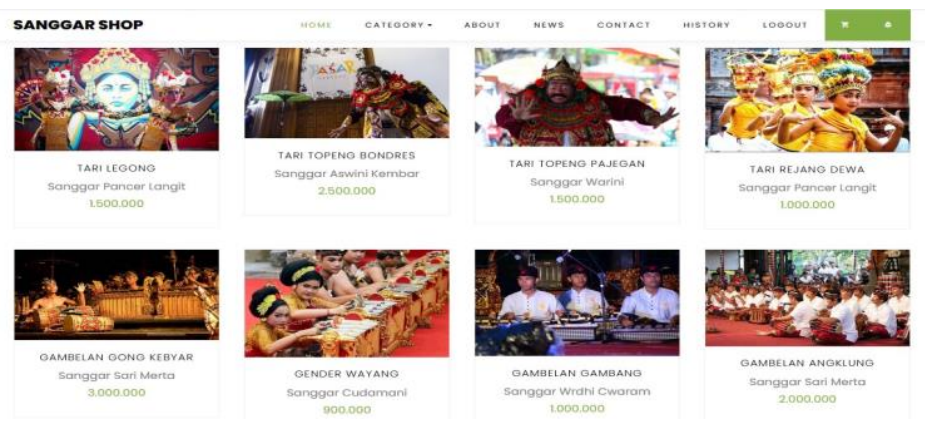

Figure 7. Balinese Traditional Performing Arts Page

Figure 7 shows various examples of traditional performing arts services from various art studios that do marketing on the system. Each performing art has listed a description, performance fees and pictures. Consumers can find information about the required performing arts as well as assist in ordering these art services. 


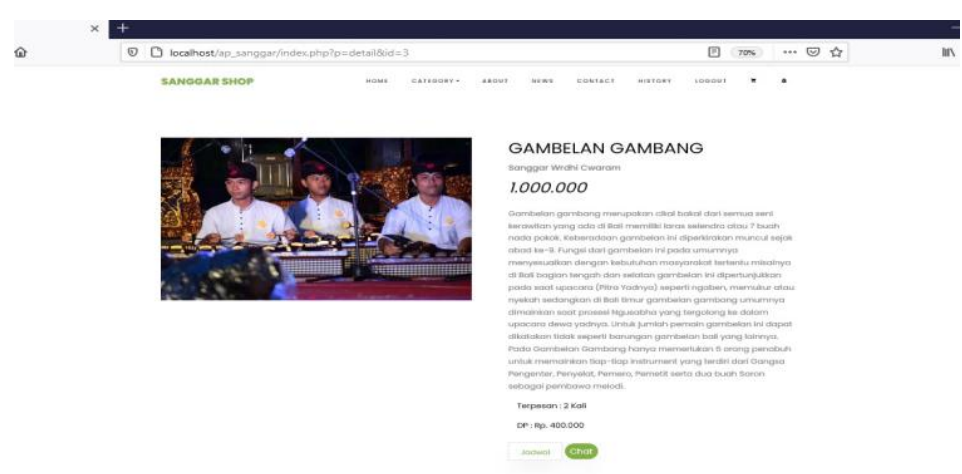

Figure 8. Performance Detail

Figure 8 is a display that will appear when consumers choose one of the performing arts services they want. The show detail display contains the show name, the art studio's name that provides the show, the total price, the description, the amount ordered, and the down payment.

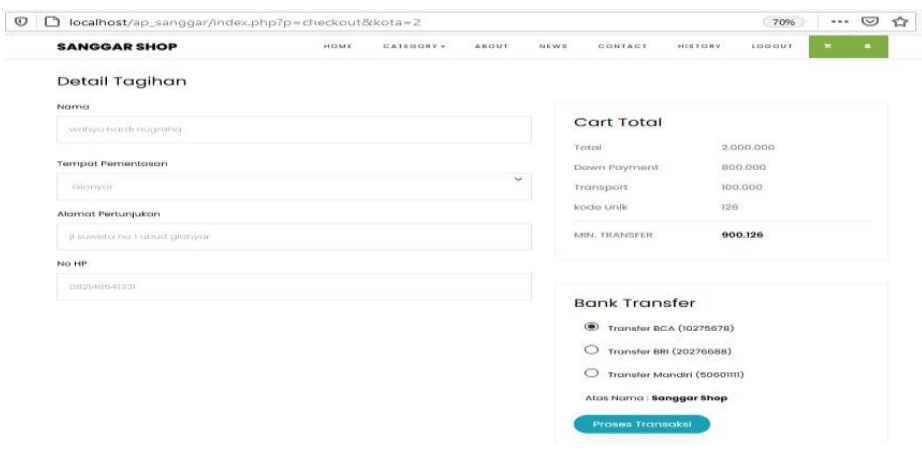

Figure 9. Checkout

Figure 9 is a display of the checkout process, which contains three forms. The first form is a billing detail containing the consumer's name, the place for the performance, the address for the performance, and the mobile number. The second form is a cart total containing the total payment, down payment, transportation costs, unique code, and the minimum transfer amount. The third form is the bank transfer account address, which can be selected according to consumer needs.

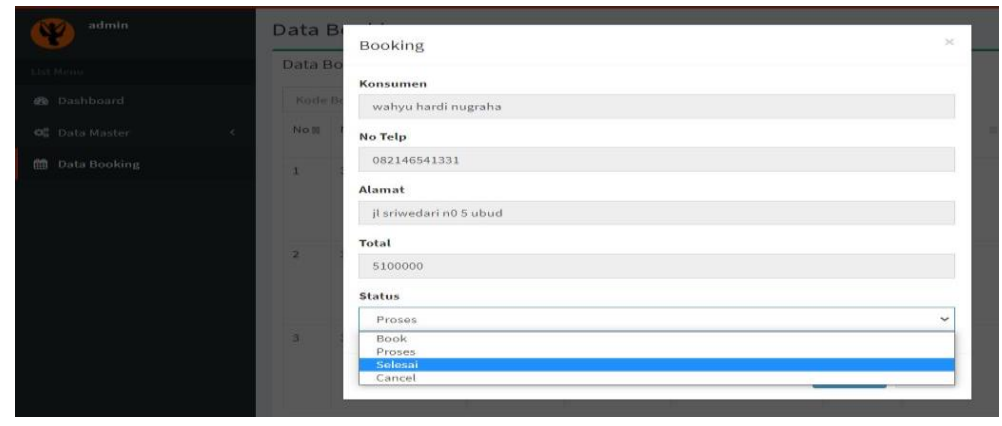

Figure 10. Administrator Verification Menu

Figure 10 is a display of the order verification menu managed by the administrator. The administrator page also contains several menus, namely dashboards, master data, and booking data, which functions to manage or verify all data in the Web-based E-Marketing Application for Balinese Art Studio. 


\subsection{Black Box Testing}

Black Box Testing is a test that defines a collection of input conditions and performs tests on the functional specifications of the program [19]. The results of this test will be listed in the following tables.

Table 1. Black Box Testing Results on Consumers

\begin{tabular}{|c|c|c|c|c|}
\hline No. & Description & Testing Scenarios & Expected Results & Result \\
\hline 1 & $\begin{array}{l}\text { This test aims to see } \\
\text { when consumers } \\
\text { have successfully } \\
\text { logged in, whether } \\
\text { they will } \\
\text { automatically go to } \\
\text { the main page } \\
\text { display or not }\end{array}$ & Consumer Log in & $\begin{array}{l}\text { The main view will } \\
\text { appear } \\
\text { automatically }\end{array}$ & success \\
\hline 2 & $\begin{array}{l}\text { This test serves to } \\
\text { determine the } \\
\text { process that occurs } \\
\text { in the product detail } \\
\text { view }\end{array}$ & $\begin{array}{l}\text { Consumers will } \\
\text { click on one of the } \\
\text { gamelans and } \\
\text { dance performing } \\
\text { arts }\end{array}$ & $\begin{array}{l}\text { The system will } \\
\text { display an image of } \\
\text { performing arts } \\
\text { services }\end{array}$ & success \\
\hline 3 & $\begin{array}{l}\text { This test aims to see } \\
\text { whether the filling of } \\
\text { the staging schedule } \\
\text { information on the } \\
\text { schedule menu has } \\
\text { gone according to } \\
\text { expectations or not }\end{array}$ & $\begin{array}{l}\text { Fill in the } \\
\text { information on the } \\
\text { performance date } \\
\text { and time of the } \\
\text { performance you } \\
\text { want, then click the } \\
\text { "save" button }\end{array}$ & $\begin{array}{l}\text { The system } \\
\text { responds by giving } \\
\text { a notification } \\
\text { "successfully } \\
\text { entered the cart," } \\
\text { which means the } \\
\text { order has entered } \\
\text { the shopping cart }\end{array}$ & success \\
\hline 4 & $\begin{array}{l}\text { This test is useful for } \\
\text { filling in checkout } \\
\text { details such as show } \\
\text { address and bank } \\
\text { transfer account } \\
\text { address }\end{array}$ & $\begin{array}{l}\text { Fill in the show } \\
\text { address, bank } \\
\text { transfer address, } \\
\text { then click the } \\
\text { "process } \\
\text { transaction" button }\end{array}$ & $\begin{array}{l}\text { Consumer orders } \\
\text { will be } \\
\text { automatically } \\
\text { stored in the history } \\
\text { menu accompanied } \\
\text { by the status of the } \\
\text { order "booked" }\end{array}$ & success \\
\hline
\end{tabular}

Table 2. The results of the Black Box Sanggar and Administrator Testing

\begin{tabular}{|c|c|c|c|c|}
\hline No. & Description & Testing Scenarios & Expected Results & Result \\
\hline 1 & $\begin{array}{l}\text { The purpose of this } \\
\text { test is to find out the } \\
\text { contents of the studio } \\
\text { booking data menu }\end{array}$ & $\begin{array}{l}\text { After successfully } \\
\text { logging in, the art } \\
\text { studio selects the } \\
\text { booking data menu } \\
\text { on the main page }\end{array}$ & $\begin{array}{l}\text { Show order data } \\
\text { appears from the } \\
\text { consumer } \\
\text { concerned }\end{array}$ & success \\
\hline 2 & $\begin{array}{l}\text { This test aims to see } \\
\text { the contents of the } \\
\text { admin booking data } \\
\text { menu }\end{array}$ & $\begin{array}{l}\text { After successfully } \\
\text { logging in, the } \\
\text { admin chooses the } \\
\text { booking data menu }\end{array}$ & $\begin{array}{l}\text { An order detail } \\
\text { appears from the } \\
\text { customer } \\
\text { concerned }\end{array}$ & success \\
\hline 3 & $\begin{array}{l}\text { This test aims to see } \\
\text { the success or failure } \\
\text { of providing } \\
\text { confirmation to } \\
\text { consumers in the } \\
\text { form of changes in } \\
\text { order status }\end{array}$ & $\begin{array}{l}\text { The admin clicks } \\
\text { the "edit" button } \\
\text { and then changes } \\
\text { the status of the } \\
\text { customer order }\end{array}$ & $\begin{array}{l}\text { The consumer } \\
\text { history menu } \\
\text { automatic display } \\
\text { order status }\end{array}$ & success \\
\hline
\end{tabular}




\section{3}

Questionnaire Analysis

This research questionnaire was calculated using a Likert Scale. The statements used in this study are called variables. Respondents were asked to complete a questionnaire to indicate their level of agreement with a series of statements [20]. The result of the percentage of the answer scale will be shown in Table 3 as follows.

Table 3. Questionnaire Percentage Results

\begin{tabular}{lccccccccccc}
\hline \multicolumn{1}{c}{$\begin{array}{c}\text { Respons } \\
\text { Variable } \begin{array}{c}\text { Rotal } \\
\text { (People) }\end{array}\end{array}$} & SS & S & N & TS & STS & SS & S & N & TS & STS \\
\hline P1 & 20 & 12 & 8 & 0 & 0 & 0 & $60 \%$ & $40 \%$ & 0 & 0 & 0 \\
P2 & 20 & 9 & 11 & 0 & 0 & 0 & $45 \%$ & $55 \%$ & 0 & 0 & 0 \\
P3 & 20 & 10 & 10 & 0 & 0 & 0 & $50 \%$ & $50 \%$ & 0 & 0 & 0 \\
P4 & 20 & 12 & 8 & 0 & 0 & 0 & $60 \%$ & $40 \%$ & 0 & 0 & 0 \\
P5 & 20 & 5 & 9 & 6 & 0 & 0 & $25 \%$ & $45 \%$ & $30 \%$ & 0 & 0 \\
P6 & 20 & 6 & 9 & 5 & 0 & 0 & $30 \%$ & $45 \%$ & $25 \%$ & 0 & 0 \\
P7 & 20 & 6 & 7 & 7 & 0 & 0 & $30 \%$ & $35 \%$ & $35 \%$ & 0 & 0 \\
P8 & 20 & 5 & 8 & 7 & 0 & 0 & $25 \%$ & $40 \%$ & $35 \%$ & 0 & 0 \\
P9 & 20 & 8 & 12 & 0 & 0 & 0 & $40 \%$ & $60 \%$ & 0 & 0 & 0 \\
\hline
\end{tabular}

Respondents answered with the percentage results included in the answer scale strongly agree and agree. Based on these results, the Web-based E-Marketing Application for Balinese Art Studio can be said to have run well, is easy to use, and responds according to the data needed. All features function well and are very suitable to be implemented.

\subsection{Comparison of Analysis Methods and Results}

The Web-based E-Marketing Application for Balinese Art Studio has several comparisons of methods and analysis results with references to previous research, which will be explained as follows.

Previous research journals used the same tools, namely UML (Unified Modeling Language). The use of UML tools focuses on the types of diagrams used in application modelling, one of which is use case diagrams, sequence diagrams and activity [2]. Comparison of comparative journal tools with the waterfall method used in this study, namely the Waterfall method does not focus too much on the type of diagram used but focuses on step by step that must be completed sequentially. The comparison of the results of the analysis with comparative journals is that both produce an e-marketing application that uses a website, but the comparative journal does not use questionnaire analysis. The next comparison based on the results of the questionnaire can be said that the applications produced by comparative journals are more likely to introduce and provide education in Balinese cultural arts, especially Gamelan Jegog [8], whereas this research tends to aim at online marketing and ordering of Balinese traditional performing arts services through a website mediator.

The research journal called The Balians has the same objective as this research, namely as a medium for promoting traditional performing arts. Research journals use the DSRM (Design Science Research Methodology) method, which in general, the flow of stages has the same scope as the Waterfall method. The trial results of comparative journals used the same calculation method as this study, namely the Likert Scale. The questionnaire results show that the comparison lies in terms of features, one of which is that the Balians system emphasizes the feature of providing tickets to watch shows with GIS (Geographic Information System) [3].

The next research journal with the Tembang Bali case study uses the Finite State Automata method, which functions to separate syllables to make it easier for users to learn the lyrics of the Balinese Tembang. The Finite State Automata method with the Waterfall method certainly has a very different scope. The Finite State Automata method focuses more on existing rules in Balinese Tembang such as the number of lines in one stanza, the last vowel and the number of syllables. The comparative journal research results use the same platform implementation as this study, namely the website, but what distinguishes it is from the system 
implementation point of view. The system's implementation in comparative journals is expected to become e-learning for elementary, middle and general school students [4].

The next research journal produced an application that helps in marketing and ordering flowers via an Android-based smartphone. Applications in comparative journals use the Hybrid Apps method, a combination of the Java programming language and PHP. Comparison of the comparative journal research results produced with the Hybrid Apps method, namely the application, can run on several platforms (mobile web) because it combines the Java and PHP languages, whereas in this study only uses one platform, namely the website [5]. Subsequent research journals produced a web-based information system that focused on individual case studies, namely the Balinese Gamelan [6] and Bayuh Oton ceremony [9]. The comparison lies in the method's flow, and the most prominent thing in the comparative journal is that there is no transaction process.

The next research journal uses the same method as this research, namely the Waterfall method. There are similarities with the comparative journal case studies, namely the art studio. The comparison of the research results lies in the features offered, one of which is the chat message feature [7]. The next journal applies the Text Mining method for word processing, the Levenshtein Distance method for automatic word correction and Latent Semantic Indexing for information processing and input-output. The comparison journals method only focuses on ecommerce search engines, while the waterfall method focuses on the flow of steps taken when designing an application. The search engine test from comparative journal research used the accuracy test, which resulted in about $96.7 \%$ using the test material in a database [10]. While in this study, the search engine did not test, but what it did was test the system's functionality using Black Box Testing.

\section{Conclusion}

This research produces an E-Marketing Application for Balinese Art Studio, which is applied in the form of a website as the mediator. This application's implementation is carried out from 3 sides of the entity, namely admin, art studio, and consumers. This application can be used as a marketing solution, and ordering performing arts services previously done manually has now turned online. Black Box testing shows the results that all functional components of the system have been running successfully. Questionnaire testing involving 20 respondents obtained results that this application has been running well, responding according to the data needed to be very suitable to be applied to the community, especially those who need assistance in ordering performing arts services. The implementation of this application has indirectly become a forum for promoting traditional Balinese performing arts.

\section{References}

[1] Santoso, "E-Marketing pada Ukm Sepatu Bunut Abang Adik Kisaran," Jurnal Teknologi dan Sistem Informasi, vol. 1, no. 2, pp. 87-91, 2015.

[2] N. Susanti, "Perancangan E-Marketing Umkm Kerajinan Tas," Jurnal Simetris Teknik Mesin, Elektro dan Ilmu Komputer, vol. 9, no. 1, pp. 717-722, 2018.

[3] I. K. A. Purnawan, I. N. Piarsa, and I. P. A. D. Winanda, "The balians: Promoting Balinese Traditional Art Exhibition using Geographic Information System," Journal Theoritical and Applied Information Technology, vol. 96, no. 15, pp. 4736-4747, 2018.

[4] A. A. Oka Sudana, P. Wira, and T. Wulandari, "Web-based Implementation of Finite State Automata Method on Lyrics Recognition System of Balinese Song 'Pupuh," International Journal of Computer Application, vol. 149, no. 4, pp. 32-37, 2016.

[5] S. A. Pratiwi, I. M. Sukarsa, I. K. A. Purnawan, "Rancang Bangun Aplikasi Sistem Pemesanan Bunga berbasis Android," Jurnal IImiah Merpati (Menara Penelitian Akademika Teknologi Informasi), vol. 2, no. 2, pp. 205-214, 2016.

[6] O. Sudana, K. C. P. I Putu, and A. Wirdiani, "Model Forest Tree dalam Sistem Informasi Gamelan Terintegrasi," Jurnal Techno.Com, vol. 19, no. 3, pp. 274-285, 2020.

[7] Taufiq dan Ermawati, "Perancangan Sistem Informasi Pemesanan Pentas Seni Berbasis Web pada Sanggar Seni Getar Pakuan Bogor," International Journal on Software 
Engineering, vol. 3, no. 2, pp. 1-7, 2017.

[8] I. P. Y. Ariatmaja, I. K. A. Purnawan, and I. P. A. Bayupati, "Rancang Bangun Aplikasi Gamelan Jegog (Barangan, Kancil, dan Tawa-Tawa) Multitouch Berbasis Android," Jurnal IImiah Merpati (Menara Penelitian Akademika Teknologi Informasi), vol. 2, no. 1, pp. 34-42, 2016.

[9] N. P. R. G. Dewi, O. Sudana, and M. Sukarsa, "Implementasi Diagram Tree pada Rancang Bangun Sistem Informasi Bebayuhan Oton Berbasis Web," Lontar Komputer Jurnal IImiah Teknologi Informasi, vol. 8, no. 3, pp. 178-187, 2017.

[10] N. M. A. Lestari and M. Sudarma, "Perencanaan Search Engine E-commerce dengan Metode Latent Semantic Indexing berbasis Multiplatform," Lontar Komputer Jurnal IImiah Teknologi Informasi, vol. 8, no. 1, pp. 31-40, 2017.

[11] Pressman, 2015. Rekayasa Perangkat Lunak: Pendekatan Praktisi Buku, Yogyakarta: Andi.

[12] A. M. Shaltoni, D. West, I. Alnawas, and T. Shatnawi, "Electronic Marketing Orientation in the Small and Medium-sized Enterprises Context," Journal Europan Business Review, vol. 30, no. 3, pp. 272-284, 2018.

[13] A. Nanik, "Pengelolaan Pembelajaran Tari Rampak Bedug di Sanggar Bale Seni Ciwasiat Pandeglang," Repository Indonesia University of Education, 2013.

[14] D. R. Susilo, D. Saripudin, and S. Moeis, "Perkembangan Sanggar Seni Tari Topeng Mulya Bhakti di Desa Tambi," Jurnal Sejarah dan Pendidikan Sejarah, vol. 7, no. 1, pp. 53-56, 2018.

[15] I. Bahardur, "Kearifan Lokal Budaya Minangkabau dalam Seni Pertunjukan Tradisional Randai," Jurnal Kajian Sastra, vol. 7, no. 2, pp. 145-160, 2018.

[16] M. A. Ramdhani, "Pemodelan Proses Bisnis Sistem Akademik menggunakan Pendekatan Business Process Modelling Notation (BPMN) (Studi Kasus Institusi Perguruan Tinggi Xyz)," Jurnal Informasi, vol. 7, no. 2, pp. 83-93, 2015.

[17] Zefriyenni and Budi," Sistem Informasi Penjualan dan Pengendalian Persediaan Barang menggunakan Metode Economic Order Quantify (EOQ) menggunakan Bahasa Pemrograman Java dan Database MYSQL pada Toko KANSA Elpij," Jurnal KomTekInfo, vol. 2, no. 2, pp. 23-32, 2015.

[18] Muslihudin and Oktafianto, 2016. Analisis dan Perancangan Sistem Informasi menggunakan Model Terstruktur dan UML. Yogyakarta: Andi.

[19] M. S. Mustaqbal, R. F. Firdaus, and H. Rahmadi, "Pengujian Aplikasi menggunakan Black Box Testing Boundary Value Analysis (Studi Kasus: Aplikasi Prediksi Kelulusan SNMPTN)," Jurnal IImiah Teknologi Informasi Terapan, vol. 1, no. 3, pp. 31-36, 2015.

[20] E. R. Karno Nur Cahyo, Martini, "Perancangan Sistem Informasi Pengelolaan Kuesioner Pelatihan pada PT Brainmatics Cipta Informatika," Journal of Information System Research, vol. 1, no. 1, pp. 45-53, 2019. 